\title{
SISTEM PAKAR UNTUK MENENTUKAN SANKSI PELANGGAR LALU LINTAS SEPEDA MOTOR DAN MOBIL MENGGUNAKAN METODE FORWARD CHAINING BERBASIS WEB
}

\author{
Agus Budiantoro ${ }^{1)}$, Atiqah Meutia Hilda,S.Kom.,M.Kom ${ }^{2)}$, \& E. Rizal M.Kom ${ }^{3)}$ \\ 1,2,3) Program Studi Informatika Fakultas Teknik Universitas Muhammadiyah \\ Prof. Dr. Hamka, Jakarta \\ Alamat Jl. Tanah Merdeka No.6 Jakarta Timur
}

Korespondensi : Atiqahmeutiahilda@uhamka.ac.id

\begin{abstract}
Abstrak - Pada saat ini untuk menentukan sanksi tilang di pengadilan masih menggunakan para pakar tanpa bantuan sistematis. Tentunya sangat disayangkan apabila teknologi tidak dimanfaatkan pada bidang ini. Permasalahan yang sama juga ada pada polisi lalu lintas yang bertugas untuk melakukan penilangan dan mensosialisasikan pasal-pasal serta denda yang berlaku bagi pelanggar lalu lintas. Maka dari itu, dalam penelitian ini, peneliti akan membuat "SISTEM PAKAR UNTUK MENENTUKAN SANKSI PELANGGAR LALU LINTAS SEPEDA MOTOR DAN MOBIL MENGGUNAKAN METODE FORWARD CHAINING BERBASIS WEB" untuk membantu hakim dalam menentukan sanksi atau denda pelanggar lalu lintas, membantu polisi dalam mensosialisasikan kepada pengendara yang melanggar lalu lintas, dan membantu pengendara untuk mengetahui peraturan, dan pasal-pasal berlalu lintas. Metode forward chaining akan lebih cocok digunakan untuk sistem tersebut karena penelitian pada bidang ini menggunakan fakta-fakta yang sudah pasti. Objek dari penilitian ini yaitu pengendara mobil dan sepeda motor. Adanya beberapa contoh kasus yang digunakan oleh peneliti berguna untuk menguji keakuratan proses atau hasil dari konsultasi ini, peneliti juga memberikan contoh kepada pengendara, polisi, dan juga pakar hukum untuk pengujian sistem pakar lalu lintas ini. Dengan tingkat validasi kebenaran yang telah tercapai maka sistem pakar lalu lintas ini dapat digunakan sebagai salah satu metode hakim, pelanggar atau polisi dalam menentukan sanksi tilang.
\end{abstract}

Kata kunci: Pasal-pasal, Lalu lintas, Forward Chaining, Sistem Pakar, Motor, Mobil.

\begin{abstract}
Nowadays, to determine the ticketed sanctions in court still using experts without systematic assistance. Certainly, it is very unfortunate if the technology is not utilized in this field. A similar problem also exists with the traffic police on duty to do out the crossing and socialize the articles and fines that apply to traffic violators. The police must also memorize the articles of traffic violations, but only those that are often violated by drivers because there are many articles on traffic violations that the police cannot memorize. Therefore, in this research, the writer creates a system to assist judges in determining sanctions or fines for traffic violators, to assist the police in socializing the traffic violator, and to assist the drivers in knowing the rules, and also the traffic articles. The Forward Chaining method would be more suitable to be used for those systems because the research field uses facts to be sure. The objects of this research are car and motorcycle riders. The existence of several case examples are used by the writer that is useful to test the accuracy of the process or the results of this consultation, researchers also provide examples to the drivers, the police, and also legal experts for testing this traffic expert system. With the level of validation of truth that has been achieved, this traffic expert system can be used as a method of judges, violators or police in determining ticketing sanctions.
\end{abstract}

Keywords: Articles, Traffic, Forward Chaining, Expert System, Motorcycle, Car. 


\section{Pendahuluan}

Di Indonesia Masih ada beberapa pelanggar yang memang masih belum mengetahui pasal-pasal berlalu lintas dan denda yang berlaku bagi pelanggar. Fakta beberapa tahun terakhir, setiap tahun jumlah pelanggar lalu lintas secara nasional selalu tinggi. Data yang dirilis Polri untuk 2012 mencapai 5.790.191 pelanggar, 2013 tembus 6.238.869 pelanggaran, 2014 naik drastis menjadi 12.009.214 pelanggaran, dan 2016 totalnya 8.497 .779 pelanggaran[3].

Sistem pakar adalah salah satu bagian dari kecerdasan buatan yang mengandung pengetahuan dan pengalaman dari seorang ahli dalam suatu area pengetahuan tertentu sehingga setiap orang dapat menggunakannya untuk memecahkan berbagai masalah yang bersifat spesifik. Sistem tersebut dapat membantu masyarakat dalam menyelesaikan masalah[4].

Forward chaining merupakan metode yang dimulai dari premis menuju kepada kesimpulan akhir, sering disebut data driven (yaitu, pencarian dikendalikan oleh data yang diberikan), artinya suatu proses yang memulai pencarian data dari premis menuju konklusi [4].

Maka dari itu peneliti mengambil judul "Sistem

Pakar untuk Menentukan Sanksi Pelanggar Lalu Lintas Sepeda Motor dan Mobil Menggunakan Metode Forward chaining Berbasis $\boldsymbol{W E B}$ ” untuk memudahkan hakim dalam menentukan sanksi pelanggar lalu lintas dengan tersistematis.

\subsection{Rumusan Masalah}

Dari penjabaran diatas terdapat beberapa masalah yaitu, bagaimana cara menerapkan metode algoritma forward chaining dalam menentukan sanksi tilang sepeda motor dan mobil secara kompleks, bagaimana cara agar pelanggar dapat mengetahui sanksi tilang dengan pasti dan bagaimana mengukur keberhasilan Algoritma Forward Chaining dalam menentukan sanksi pelanggar lalu lintas sepeda motor dan mobil?.

\subsection{Tujuan Penelitian}

Dalam menerapkan Algoritma Forward Chaining ke sebuah sistem untuk menentukan sanksi pelanggar lalu lintas sepeda motor dan mobil, merancang sistem pakar menggunakan forward chaining dengan cara menelusuri setiap pertanyaan, maka akan terdeteksi setiap pelanggaran yang dilanggar oleh pengendara secara detail dan dengan cara menyebarkan kuesioner ke pengguna dan memberi contoh kasus dapat menyimpulkan keberhasilan dalam penerapan Algoritma Forward Chaining untuk menentukan sanksi pelanggar lalu lintas sepeda motor dan mobil.

\subsection{Manfaat Penelitian}

Sistem pakar untuk menentukan sanksi pelanggar lalu lintas dengan forward chaining ini memudahkan penelitian selanjutnya dalam mengambangkan sistem pakar ini, dan sistem pakar ini bisa menjadi solusi dalam menentukan sanksi tilang secara kompleks dan sistem ini bisa menjadi solusi untuk penyimpanan data pelanggar dengan skala besar dan dapat memudahkan pegawai kejaksaan dalam mencari data terdahulu.

\section{Landasan Teori}

\subsection{Sistem Pakar}

Sistem pakar sendiri merupakan sistem yang didalamnya terdapat pengetahuan yang melingkupi suatu bidang permasalahan, dan pengetahuan tersebut didasari oleh para ahli dibidangnya.

\subsection{Arsitektur Sistem Pakar}

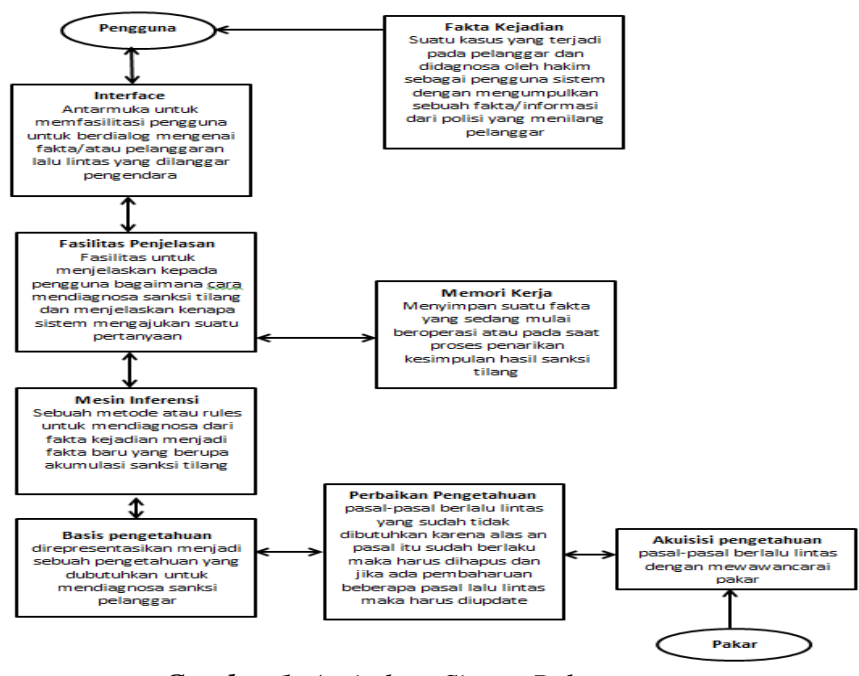

Gambar 1 Arsitektur Sistem Pakar

\subsubsection{Antarmuka Pengguna}

Pada saat user membuka halaman diagnosa sistem akan menampilkan beberapa pertanyaan ke user, sebelum itu sistem akan meminta user untuk memilih jenis kendaraan yang ingin didiagnosa.

\subsubsection{Basis Pengetahuan}

Setelah akuisisi pengetahuan tentang pasal-pasal berlalu lintas selesai dilakukan, maka pengetahuan tersebut harus direpresentasikan menjadi sebuah informasi atau fakta baru.

\subsubsection{Akuisisi Pengetahuan}

Pada tahap ini peneliti mengumpulkan data pengetahuan melalui jurnal ilmiah, internet, dan mewawancarai para pakar dibidangnya. Setelah mendapatkan data-data yang dibutuhkan sistem peneliti mempelajari dan mengolah data-data tersebut menjadi tersusun rapih untuk dijadikan basis pengetahuan.

\subsubsection{Mesin Inferensi}

Mesin inferensi yang dipakai untuk sistem pakar ini yaitu metode forward chaining dimana setiap pertanyaan yang diajukan sistem bertujuan untuk menghasilkan suatu kesimpulan akhir.

\subsubsection{Memori Kerja}

Hasil dari penentuan sanksi tilang akan terekam dalam memori kerja pada sistem. 


\subsubsection{Fasilitas Penjelasan}

Pada sistem ini terdapat suatu penjelasan untuk user tentang bagaimana sistem ini berjalan, bagaimana cara mencapai konklusi yang diinginkan.

\subsubsection{Perbaikan Pengetahuan}

Pada sistem pakar ini terdapat knowladge base yang diharapkan berguna sebagaimana mestinya, akan tetapi beberapa informasi yang ada pada knowledge base bisa saja suatu saat nanti ada yang sudah tidak dibutuhkan dikarenakan suatu alasan tertentu. Admin yang bertugas sebagai pemelihara sistem akan mengevaluasi setiap kelakuan sistem yang tidak sesuai dengan yang diharapkan.

\subsubsection{Fakta Kejadian}

Pengguna sistem akan menerima data-data pengendara yang melanggar lalu lintas dari polisi lalu lintas yang menindak pelanggar, pengguna akan mendiagnosa dari kasus pengendara yang melanggar lalu lintas.

\subsection{Metode Forward chaining}

Metode ini adalah salah satu dari dua metode utama dalam keceradasan buatan, yang dapat dideskripsikan secara logika. Contoh:

Terdapat enam peraturan yang tersimpan dalam basis pengetahuan yaitu:

R1: if $A$ and $B$ then $C$
R2: if $A$ then $C$
R3: if $C$ and $D$ then $E$
R4: if $D$ and $B$ then $G$
R5: if D then $F$
R6: if $F$ then $H$

Fakta awal yang diberikan hanya A dan B, ingin membuktikan apakah $\mathrm{H}$ bernilai benar. Proses penalaran forward chaining terlihat pada Gambar 2.2[4].

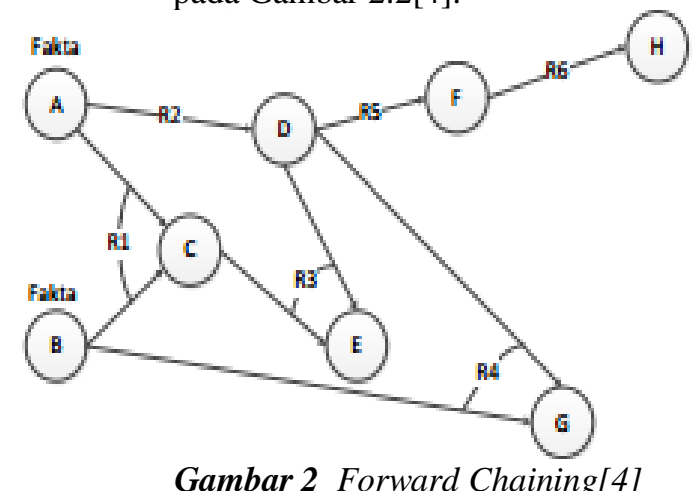

\subsection{Tata Tertib Lalu Lintas}

Peraturan dan undang-undang lalu lintas di Indonesia menyangkut segala aspek dalam kehidupan bermasyarakat. Kegiatan berlalu lintas adalah hal yang sangat penting dalam menjalani kehidupan sosial. Sebagai negara hukum,
Indonesia mempunyai undang-undang yang megatur setiap aspek kehidupan bernegara[1]. Dimana pasal-pasal berlalu lintas tersebut adalah sebagia berikut:

1. Pasal 280 kendaraan bermotor yang tidak dipasangi plat nomor kepolisian akan dipidana kurungan paling lama 2 bulan atau denda paling banyak $\mathrm{Rp}$ $500.000,00$.

2. Pasal 281 kendaraan bermotor yang tidak memiliki SIM akan dipidana kurungan paling lama 4 bulan atau denda paling banyak Rp1.000.000,00.

3. Pasal 282 pengendara tidak mematuhi perintah yang diberikan petugas kepolisian akan dipidana kurungan paling lama 1 bulan atau denda paling banyak Rp250.000,00.

4. Pasal 283 pengendara mengemudi dengan cara yang tidak wajar dan melakukan kegiatan yang menggangu konsentrasi dalam mengemudi akan dipidana kurungan paling lama 3 bulan atau denda paling banyak Rp750.000,00.

5. Pasal 285 ayat 1 pengendara sepeda motor yang tidak mematuhi persyaratan teknis dan laik jalan akan dipidana kurungan paling lama 1 bulan atau denda paling banyak Rp250.000,00.

6. Pasal 285 ayat 2 pengendara kendaraan beroda empat yang tidak mematuhi persyaratan teknis akan dipidana kurungan paling lama 2 bulan atau denda paling banyak Rp500.000,00.

7. Pasal 288 ayat 1 pengendara yang tidak melengkapi persyaratan mengemudi seperti SIM atau STCKB akan dipidana dengan kurungan paling lama 2 bulan atau denda paling banyak Rp500.000,00.

8. Pasal 288 ayat 2 pengendara yang tidak dapat menunjukan SIM yang sah akan dipidana kurungan paling lama 1 bulan atau denda paling banyak Rp250.000,00.

9. Pasal 288 ayat 3 pengendara mobil penumpang umum, mobil bus, mobil barang, kereta gandengan, dan kereta tempelan yang tidak dilengkapi dengan surat keterangan uji berkala tanda lulus uji berkala akan dipidana kurungan paling lama 2 bulan atau denda paling banyak Rp500.000,00.

10. Pasal 289 pengemudi dan penumpang yang duduk disamping pengemudi tidak memakai sabuk keselamatan akan dipidana kurungan paling lama 1 bulan atau denda paling banyak Rp250.000,00.

11. Pasal 291 ayat 1 pengendar sepeda motor yang tidak memakai helm standar nasional Indonesia akan dipidana kurungan paling lama 1 bulan dan denda paling banyak Rp250.000,00.

12. Pasal 291 ayat 2 pengendar sepeda motor yang membiarkan penumpangnya tidak memakai helm akan dipidana kurungan paling lama 1 bulan dan denda paling banyak Rp250.000,00.

13. Pasal 292 pengendara sepeda motor tanpa kereta samping yang mengangkut lebih dari satu penumpang akan dipidana kurungan paling lama 1 bulan atau denda paling banyak Rp250.000,00.

14. Pasal 293 ayat 1 pengendara bermotor mengemudi tanpa menyalakan lampu utama pada malam hari dan 
kondisi tertentu akan dipidana kurung paling lama 1 bulan atau denda paling banyak Rp250.000,00.

15. Pasal 293 ayat 2 pengendara bermotor mengemudi tanpa menyalakan lampu utama pada siang akan dipidana kurung paling lama 15 hari atau denda paling banyak Rp100.000,00.

16. Pasal 294 pengendara bermotor yang akan membelok atau berbalik arah, tanpa memberikan isyarat dengan lampu penunjuk arah atau isyarat tangan akan dipidana kurungan paling lama 1 bulanatau denda paling banyak Rp250.000,00.

17. Pasal 298 pengendara bermotor yang tidak memasang segitiga pengaman, lampu isyarat peringatan bahaya, atau isyarat lain pada saat berhenti atau parkir dalam keadaan darurat di jalan akan dipidana kurungan paling lama 2 bulan atau denda paling banyak Rp500.000,00.

18. Pasal 306 pengendara angkutan barang yang tidak dilengkapi surat muatan dokumen perjalanan akan dipidana kurungan paling lama 1 bulan atau denda paling banyak Rp250.000,00.

19. Pasal 307 pengendara angkutan umum barang yang tidak mematuhi ketentuan mengenai tata cara pemuatan, daya angkut, dimensi kendaraan akan dipidana kurungan paling lama 2 bulan atau denda paling banyak Rp500.000,00.

\subsection{Analisis Penelitian Sebelumnya}

2.5.1. Expert System Pelanggaran Kendaraan Bermotor Di Indonesia Dengan Metode Forward Chaining[1].

2.5.2. Sistem Pakar Menentukan Sanksi Tilang Lalu Lintas Angkutan Jalan (LLAJ) Dengan Menggunakan Metode Forward Chaining (Studi Kasus Pengadilan Negeri Tembilahan)[2].

\subsection{Perbandiangan}

Berdasarkan penelitian [1] dan [2] metode yang cocok untuk menentukan sanksi tilang lalu lintas yaitu forward chaining karena kasus yang diambil menggunakan faktafakta yang sudah pasti. Pada penelitian [1] mempunyai kekurangan yaitu objek yang diambil hanya kendaraan bermotor dan juga saat sistem mengajukan salah satu pertanyaan "Apakah anda sudah mempunyai sim?" jika user memilih "ya" maka lanjut ke pertanyaan selanjutnya dan jika user memilih "tidak" maka proses berhenti dan sistem akan menampilkan hasil pelanggaran user, lalu bagaimana jika user melanggar lebih dari satu pelanggaran?, maka dari itu peneliti akan mengembangkan sistem pakar menggunakan metode forward chaining ini dengan tidak hanya kendaraan bermotor saja tetapi setiap pengendara lalu lintas dan jika sistem mengajukan salah satu pertanyaan dan ketika user memilih "ya" ataupun "tidak" maka sistem akan lanjut ke pertanyaan selanjutnya hingga pertanyaan yang diajukan oleh sistem selesai, dari situ kita bisa melihat pelanggaran, pasal-pasal dan juga sanksi yang diberikan oleh user.

\section{Metodologi Penelitian}

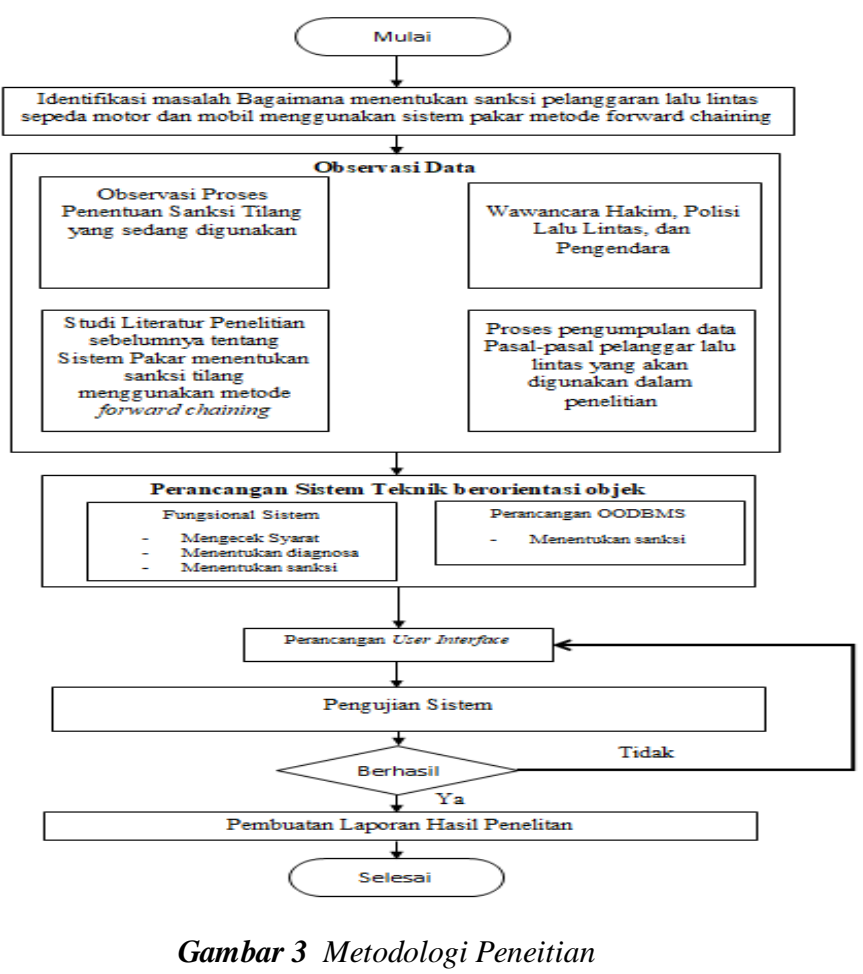

\subsection{Identifikasi Masalah Sistem Pakar Penentuan} Sanksi Tilang

Pada tahap ini peneliti akan mencatat semua permasalahan yang ada pada sistem pakar penentuan sanksi tilang dan menentukan rumusan masalah yang terjadi pada sistem tersebut. Pada tahap ini juga membatasi masalah pada sistem sehingga penelitian ini tidak menyimpang dan dapat mencapai tujuan yang diinginkan.

3.2. Observasi Proses Penentuan Sanksi Tilang yang sedang digunakan

Pada tahap ini peneliti melakukan pengamatan dengansecara langsung dan melakukan wawancara kepada Hakim, Polisi Lalu Lintas, dan juga para pengendara.

3.3. Wawancara Hakim, Polisi Lalu Lintas, dan Pengendara

Pada tahap ini peneliti mewawancarai Hakim untuk penentuan denda tilang sesuai pasal yang dilanggar oleh pengendara, dan mewawancarai Polisi Lalu Lintas untuk menanyakan bagaimana cara besosialisasi tentang pasal-pasal berlalu lintas, serta mewawancarai pengendara untuk menanyakan pengetahuan mereka tentang peraturan lalu lintas.

\subsection{Studi Literatur}

Mencari jurnal-jurnal yang berkaitan dengan sistem pakar menentukan sanksi tilang dan buku-buku tentang pasal-pasal berlalu lintas, metode Forward Chaining, sebagai teori dasar penelitian ini.

\section{$e$. Proses Pengumpulan Data}

Pada tahap ini peneliti mencari data-data yang diperlukan seperti pasal-pasal pelanggaran lalu lintas untuk dimasukan ke dalam sistem dan data penilangan 
pengendara untuk mencocokan User Interface pada sistem. Untuk mendapatkan data primer metode yang digunakan yaitu dengan wawancara tidak terstruktur kepada pihak kepolisian, kejaksaan dan pengendara. Untuk mendapatkan data sekunder metode yang digunakan yaitu studi dokumen yang meneliti berbagai macam dokumen yang berguna untuk bahan analisis.

\subsection{Prancangan Sistem}

Pada tahap ini perancangan dimulai dari relasi antar data di dalam suatu database, setelah itu merancang User Interface disesuaikan dengan data yang sudah ada di database, dan menyesuaikan data dengan rule-rule yang sudah diatur di dalam sistem.

\section{Hasil dan Pembahasan}

\subsection{Use Case Diagram}

Dengan membuat use case diagram dapat mempermudah mengetahui bagaimana pengguna jika ingin mendiagnosa kasus pelanggar lalu lintas, bagaimana sistem bisa menentukan hasil diagnosa kasus tersebut, bagaimana pengguna mengetahui pasal-pasal yang ingin diketahui, dan bagaimana sistem menampilkan hasil tersebut. User akan melakukan konsultasi untuk kasus pelanggaran lalu lintas, untuk konsultasi kasus pelanggaran lalu lintas maka user terlebih dahulu menjawab pertanyaan tentang persyaratan lalu lintas yang dilanggar oleh pelanggar, setelah itu user mendapatkan hasil konsultasi setelah beberapa pertanyaan dijawab oleh user.

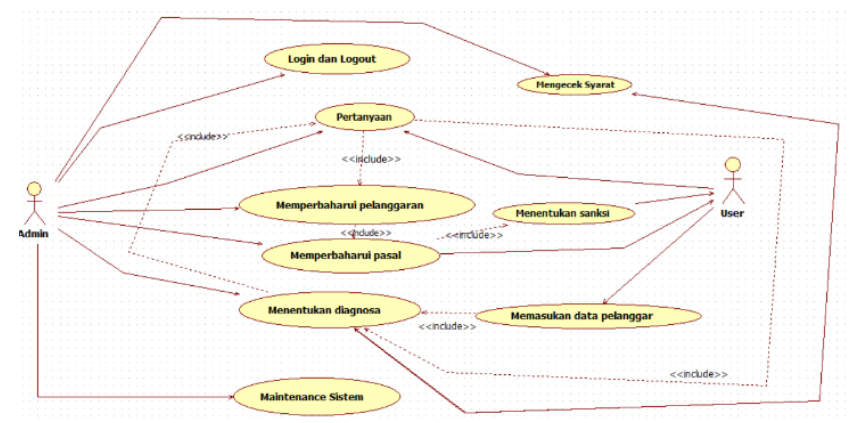

Gambar 4 Use Case Diagram

\subsection{Implementasi Interface Halaman Utama}

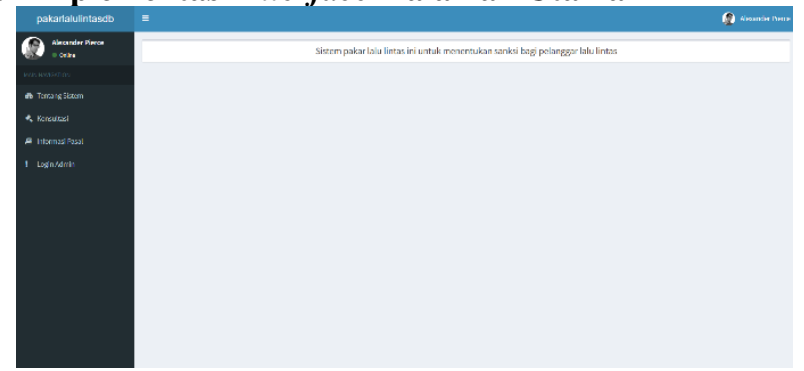

Gambar 5 Halaman Utama

Pada awal admin membuka sistem maka halaman yang pertama kali muncul adalah halaman utama, pada halaman utama terdapat menu tentang sistem, sistem informasi, konsultasi dan login admin. Pada saat membuka halaman utama maka menu tentang sistem yang akan tampil.

\subsection{Halaman Login Admin}

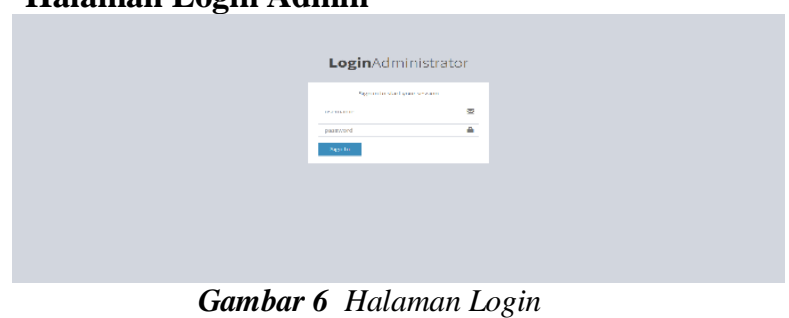

Pada halaman ini admin dipersilahkan mengisi username dan password untuk bisa mengakses halaman admin, jika username dan password salah maka akan muncul warning "username atau password salah" dan akan memuat halaman login admin kembali jika username dan password cocok makan sistem akan membawa admin ke halaman admin.

\subsection{Halaman Mengelolah Pertanyaan}

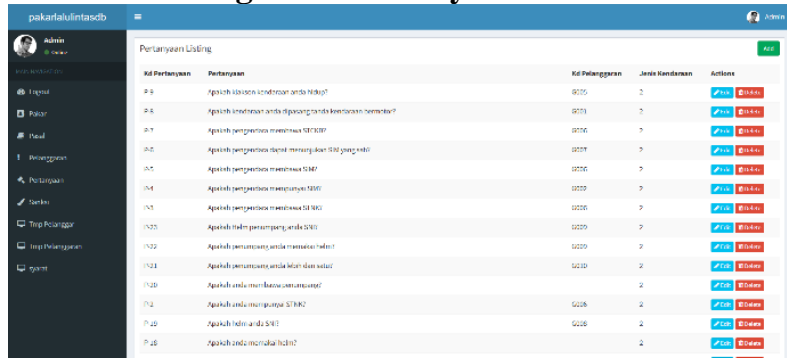

Gambar 7 Mengolah Pertanyaan

Di halaman ini admin dapat mengubah dan menghapus data pada sub menu "listing", admin juga dapat menambahkan data pertanyaan pada sub menu "add".

\subsection{Halaman Mengolah Pelanggaran}

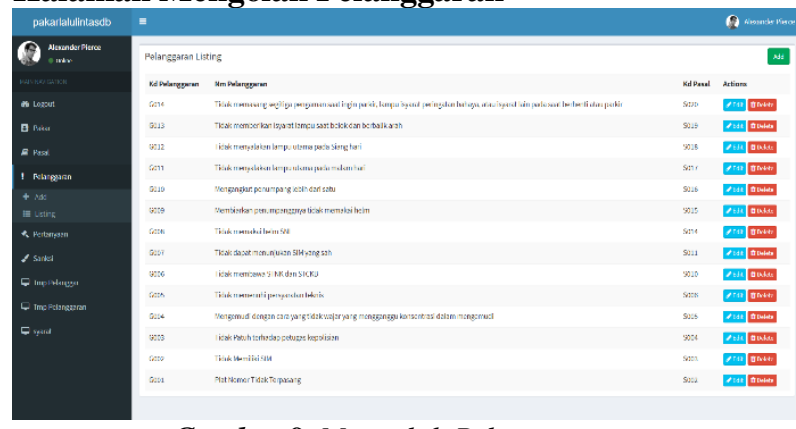

Gambar 8 Mengolah Pelanggaran

Pada halaman ini admin dapat mengubah dan menghapus data pada sub menu "listing", admin juga dapat menambahkan data pelanggaran pada sub menu "add". 


\subsection{Halaman Mengolah Pasal}

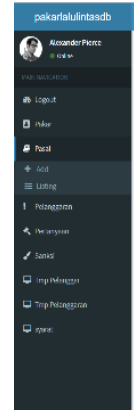

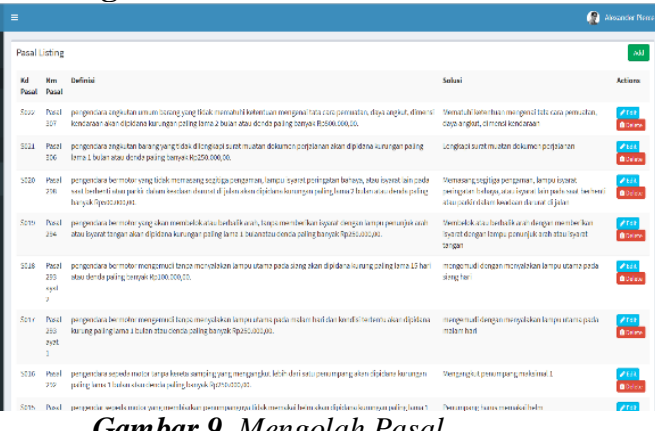

Gambar 9 Mengolah Pasal

Pada halaman pasal admin dapat mengubah dan menghapus data pada sub menu "listing", admin juga dapat menambahkan pasal pada sub menu " $a d d$ ".

4.7. Halaman Mengelolah Syarat

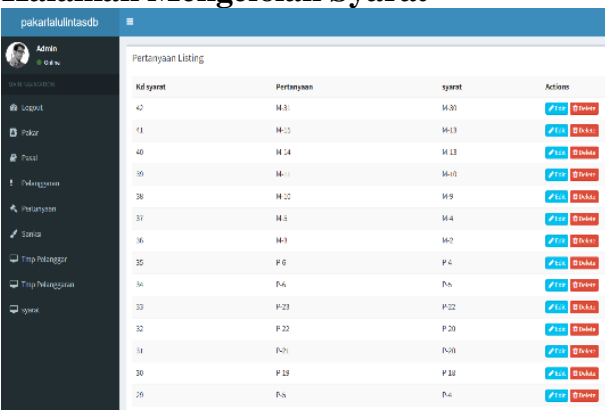

Gambar 10 Mengolah Syarat

Pada halaman mengolah syarat admin dapat mengubah dan menghapus data pada sub menu "listing", admin juga dapat menambahkan syarat pada sub menu "add".

\subsection{Halaman Konsultasi}
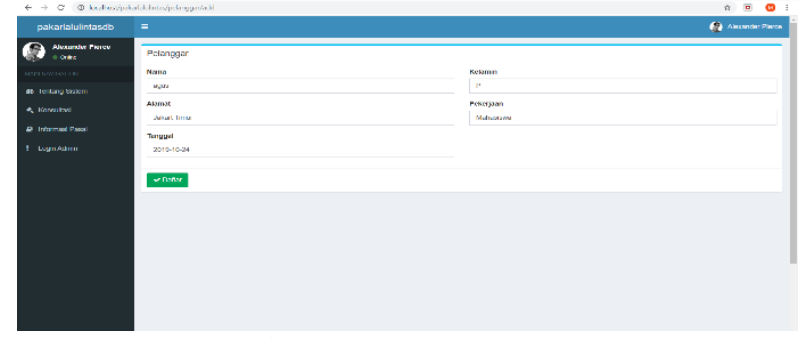

Gambar 11 Biodata Pelanggar

Pada gambar 10 ditampilkan halaman form biodata untuk mengisi data pelanggar setelah itu akan lanjut ke halaman pertanyaan awal untuk memilih jenis kendaraan yang dipakai pelanggar.

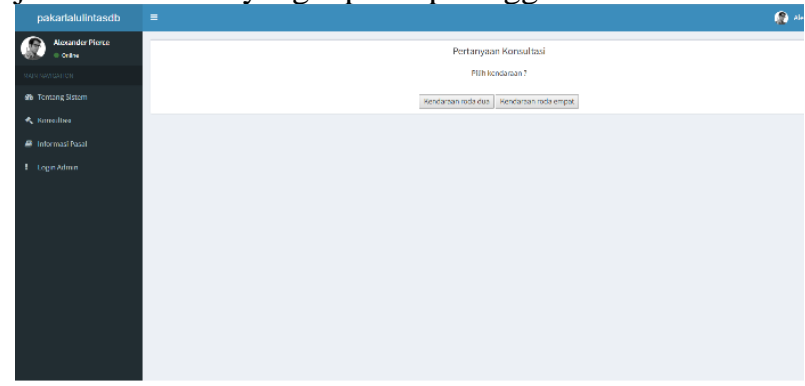

Gambar 11 Pilih Jenis Kendaraan

Pelanggar memilih kendaraan roda dua sesuai dengan kendaraan yang pelanggar pakai.
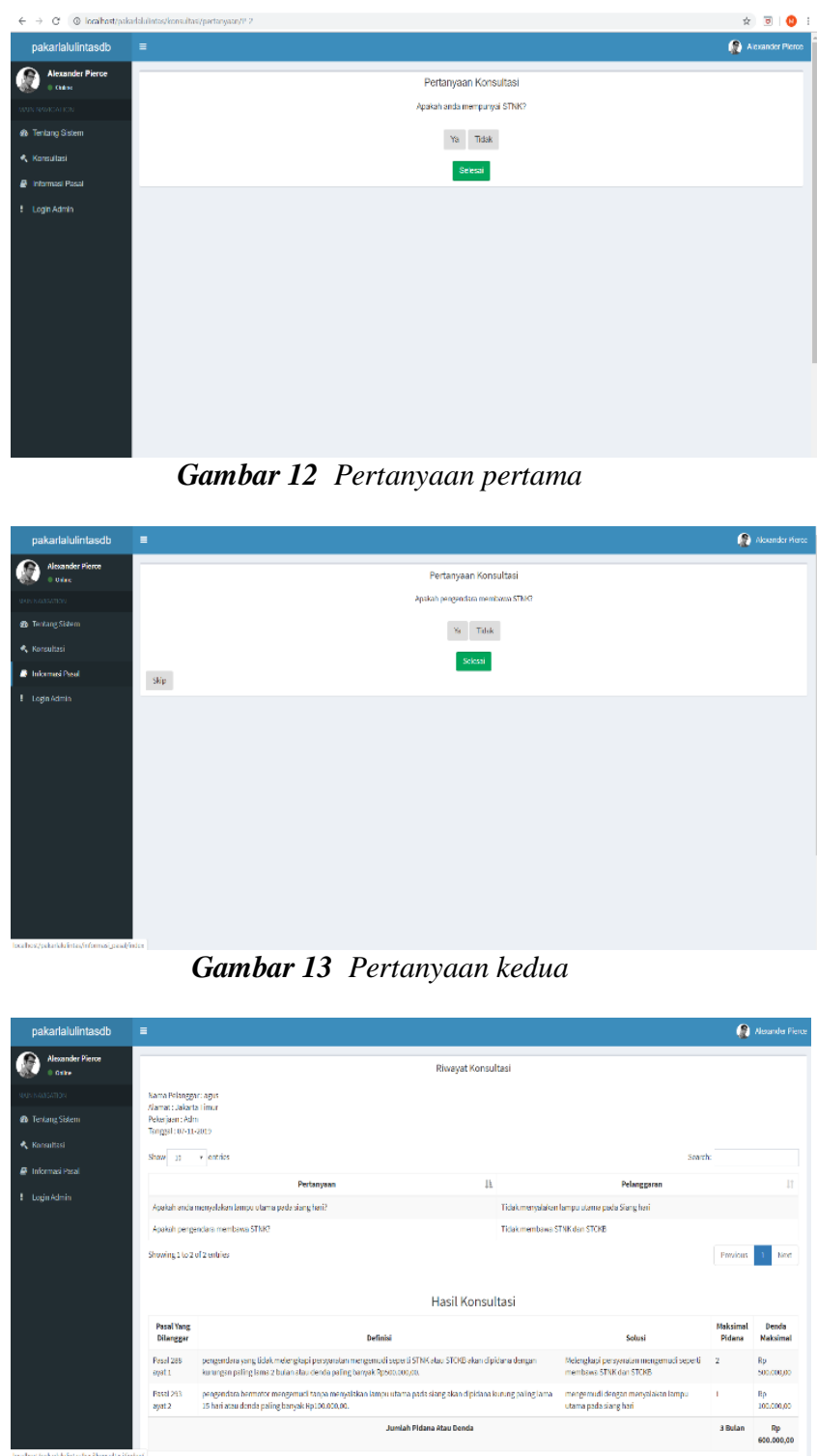

Gambar 14 Hasil Konsultasi

Menampilkan hasil konsultasi sesuai dengan contoh kasus diatas. Denda yang diderita pelanggar sesuai dengan pasal yang dilanggar.

\subsection{Halaman Informasi Pasal}
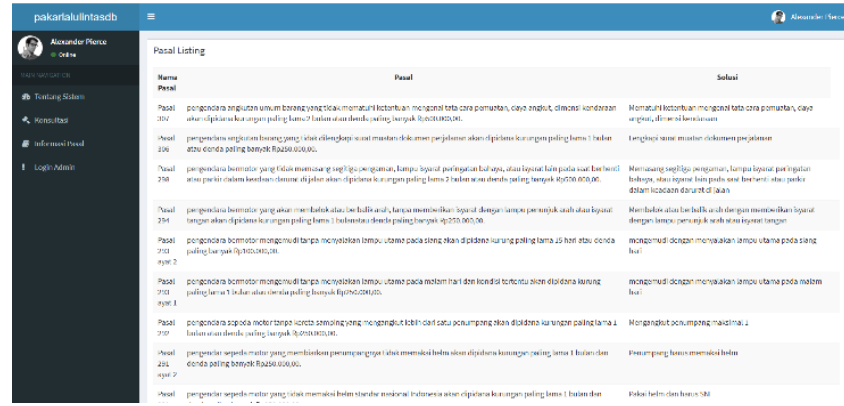

Gambar 15 Informasi Pasal

Menampilkan semua pasal lalu lintas beserta denda dan solusinya, penulis melakukan hidden terhadap kode pasal dari setiap pasal agar kode pasal tidak tampil pada tampilan informasi pasal. 


\subsection{Pengujian Sistem}

Pada tabel 1 dalam pengujian sistem pakar lalu lintas ini dilakukan dengan menggunakan metode Black box testing untuk memeriksa apakah fitur-fitur yang ada pada sistem ini berjalan sesuai dengan yang diharapkan.

\begin{tabular}{|c|c|c|c|}
\hline $\begin{array}{c}\text { Menu } \\
\text { yang diuji }\end{array}$ & Pengujian & Hasil & $\begin{array}{c}\text { Keterang } \\
\text { an } \\
\end{array}$ \\
\hline $\begin{array}{l}\text { Login } \\
\text { Admin }\end{array}$ & Admin login & $\begin{array}{l}\text { Admin dapat } \\
\text { masuk ke } \\
\text { halaman admin }\end{array}$ & Berhasil \\
\hline Logout & Admin logout & $\begin{array}{l}\text { Admin dapat } \\
\text { keluar dari } \\
\text { halaman admin } \\
\text { ke halaman } \\
\text { utama }\end{array}$ & Berhasil \\
\hline $\begin{array}{l}\text { Informasi } \\
\text { Pasal }\end{array}$ & $\begin{array}{l}\text { Melihat Informasi } \\
\text { pasal-pasal lalu } \\
\text { llintas }\end{array}$ & $\begin{array}{l}\text { Menampilkan } \\
\text { pasal-pasal lalu } \\
\text { lintas }\end{array}$ & Berhasil \\
\hline \multirow{4}{*}{ Konsultasi } & $\begin{array}{l}\text { Mengisikan } \\
\text { biodata pelanggar }\end{array}$ & $\begin{array}{l}\text { Data pelanggar } \\
\text { dapat tersimpan } \\
\text { dan sistem } \\
\text { menampilkan } \\
\text { halaman } \\
\text { pertanyaan } \\
\text { pertama }\end{array}$ & Berhasil \\
\hline & $\begin{array}{l}\text { Memilih jenis } \\
\text { kendaraan }\end{array}$ & $\begin{array}{l}\text { Sistem } \\
\text { menampilkan } \\
\text { pertanyaan sesuai } \\
\text { jenis kendaraan } \\
\text { yang pelanggar } \\
\text { pilih }\end{array}$ & Berhasil \\
\hline & $\begin{array}{l}\text { Menjawab setiap } \\
\text { pertanyaan }\end{array}$ & $\begin{array}{l}\text { Jawaban berhasil } \\
\text { tersimpan dan } \\
\text { menampilkan } \\
\text { pertanyaan } \\
\text { selanjutnya }\end{array}$ & Berhasil \\
\hline & $\begin{array}{l}\text { Mendiagnosa } \\
\text { pertanyaan yang } \\
\text { sudah dijawab } \\
\text { oleh pelanggar }\end{array}$ & $\begin{array}{l}\text { Menampilkan } \\
\text { hasil diagnosa } \\
\text { yaitu pasal, } \\
\text { solusi, dan sanksi } \\
\text { sesuai dengan } \\
\text { jawaban } \\
\text { pelanggar }\end{array}$ & Berhasil \\
\hline \multirow[t]{3}{*}{$\begin{array}{l}\text { Halaman } \\
\text { kelola } \\
\text { pasal }\end{array}$} & Add & $\begin{array}{l}\text { Data pasal } \\
\text { berhasil } \\
\text { tersimpan ke } \\
\text { database }\end{array}$ & Berhasil \\
\hline & Edit & $\begin{array}{l}\text { Data pasal dapat } \\
\text { diubah dan } \\
\text { tersimpan ke } \\
\text { database }\end{array}$ & Berhasil \\
\hline & Delete & $\begin{array}{l}\text { Data pasal dapat } \\
\text { terhapus }\end{array}$ & Berhasil \\
\hline \multirow[t]{3}{*}{$\begin{array}{l}\text { Halaman } \\
\text { Kelola } \\
\text { pelanggara } \\
\mathrm{n}\end{array}$} & Add & $\begin{array}{l}\text { Data pasal } \\
\text { berhasil } \\
\text { tersimpan ke } \\
\text { database }\end{array}$ & Berhasil \\
\hline & Edit & $\begin{array}{l}\text { Data pasal dapat } \\
\text { diubah dan } \\
\text { tersimpan ke } \\
\text { database }\end{array}$ & Berhasil \\
\hline & Delete & $\begin{array}{l}\text { Data pasal dapat } \\
\text { terhapus }\end{array}$ & Berhasil \\
\hline $\begin{array}{l}\text { Halaman } \\
\text { Kelola }\end{array}$ & Add & $\begin{array}{l}\text { Data pasal } \\
\text { berhasil }\end{array}$ & Berhasil \\
\hline
\end{tabular}

\begin{tabular}{|c|c|c|c|}
\hline \multirow[t]{3}{*}{ Pertanyaan } & & $\begin{array}{l}\text { tersimpan ke } \\
\text { database }\end{array}$ & \\
\hline & Edit & $\begin{array}{l}\text { Data pasal dapat } \\
\text { diubah dan } \\
\text { tersimpan ke } \\
\text { database }\end{array}$ & Berhasil \\
\hline & Delete & $\begin{array}{l}\text { Data pasal dapat } \\
\text { terhapus }\end{array}$ & Berhasil \\
\hline \multirow[t]{3}{*}{$\begin{array}{l}\text { Halaman } \\
\text { Kelola } \\
\text { syarat }\end{array}$} & Add & $\begin{array}{l}\text { Data pasal } \\
\text { berhasil } \\
\text { tersimpan ke } \\
\text { database }\end{array}$ & Berhasil \\
\hline & Edit & $\begin{array}{l}\text { Data pasal dapat } \\
\text { diubah dan } \\
\text { tersimpan ke } \\
\text { database }\end{array}$ & Berhasil \\
\hline & Delete & $\begin{array}{l}\text { Data pasal dapat } \\
\text { terhapus }\end{array}$ & Berhasil \\
\hline \multirow[t]{3}{*}{$\begin{array}{l}\text { Halaman } \\
\text { kelola } \\
\text { Tmp_pela } \\
\text { nggar }\end{array}$} & Add & $\begin{array}{l}\text { Data pasal } \\
\text { berhasil } \\
\text { tersimpan ke } \\
\text { database } \\
\end{array}$ & Berhasil \\
\hline & Edit & $\begin{array}{l}\text { Data pasal dapat } \\
\text { diubah dan } \\
\text { tersimpan ke } \\
\text { database }\end{array}$ & Berhasil \\
\hline & Delete & $\begin{array}{l}\text { Data pasal dapat } \\
\text { terhapus }\end{array}$ & Berhasil \\
\hline \multirow[t]{3}{*}{$\begin{array}{l}\text { Halaman } \\
\text { kelola } \\
\text { Tmp_pela } \\
\text { nggaran }\end{array}$} & Add & $\begin{array}{l}\text { Data pasal } \\
\text { berhasil } \\
\text { tersimpan ke } \\
\text { database }\end{array}$ & Berhasil \\
\hline & Edit & $\begin{array}{l}\text { Data pasal dapat } \\
\text { diubah dan } \\
\text { tersimpan ke } \\
\text { database } \\
\end{array}$ & Berhasil \\
\hline & Delete & $\begin{array}{l}\text { Data pasal dapat } \\
\text { terhapus }\end{array}$ & Berhasil \\
\hline \multirow[t]{3}{*}{$\begin{array}{l}\text { Halaman } \\
\text { kelola } \\
\text { Sanksi }\end{array}$} & Add & $\begin{array}{l}\text { Data pasal } \\
\text { berhasil } \\
\text { tersimpan ke } \\
\text { database }\end{array}$ & Berhasil \\
\hline & Edit & $\begin{array}{l}\text { Data pasal dapat } \\
\text { diubah dan } \\
\text { tersimpan ke } \\
\text { database } \\
\end{array}$ & Berhasil \\
\hline & Delete & $\begin{array}{l}\text { Data pasal dapat } \\
\text { terhapus }\end{array}$ & Berhasil \\
\hline
\end{tabular}




\subsection{Kuesioner}

Tabel 3 Skala Likert Respone Pengendara

\begin{tabular}{|c|c|c|c|c|c|c|c|c|c|c|c|}
\hline \multicolumn{12}{|c|}{$\begin{array}{l}\text { Kuesioner Responden Untuk Sistem Pakar Menentukan } \\
\text { Sanksi Pelanggar Lalu Lintas Motor dan Mobil } \\
\text { Menggunakan Metode Forward Chaining Berbasis WEB }\end{array}$} \\
\hline \multirow{2}{*}{$\begin{array}{l}\mathbf{N} \\
\mathbf{o .}\end{array}$} & \multicolumn{4}{|c|}{ Skor } & \multirow{2}{*}{$\begin{array}{c}\text { N- } \\
\text { Max }\end{array}$} & \multicolumn{4}{|c|}{$\begin{array}{c}\text { Jumlah } \\
\text { Skor }\end{array}$} & \multirow{2}{*}{ Jumlah } & \multirow{2}{*}{$\begin{array}{l}\text { Pers } \\
\text { enta } \\
\text { se } \\
(\%)\end{array}$} \\
\hline & 1 & 2 & 3 & 4 & & 1 & 2 & 3 & 4 & & \\
\hline 1. & 0 & 0 & 1 & 1 & \multirow{7}{*}{8} & 0 & 0 & 3 & 4 & 7 & 88 \\
\hline 2. & 0 & 0 & 0 & 2 & & 0 & 0 & 0 & 8 & 8 & 100 \\
\hline 3. & 0 & 0 & 1 & 1 & & 0 & 0 & 3 & 4 & 7 & 88 \\
\hline 4. & 0 & 0 & 0 & 2 & & 0 & 0 & 0 & 8 & 8 & 100 \\
\hline 5. & 0 & 0 & 0 & 2 & & 0 & 0 & 0 & 8 & 8 & 100 \\
\hline 6. & 0 & 0 & 1 & 1 & & 0 & 0 & 3 & 4 & 7 & 88 \\
\hline 7. & 0 & 0 & 1 & 1 & & 0 & 0 & 3 & 4 & 7 & 88 \\
\hline \multicolumn{3}{|c|}{$\begin{array}{c}\text { Rerata } \\
(\%)\end{array}$} & & & & & & & & \multirow[t]{2}{*}{ Jumlah } & \multirow[t]{2}{*}{652} \\
\hline & 93 & & & & & & & & & & \\
\hline
\end{tabular}

Tabel 3 Skala Likert Respone Polisi lalu lintas

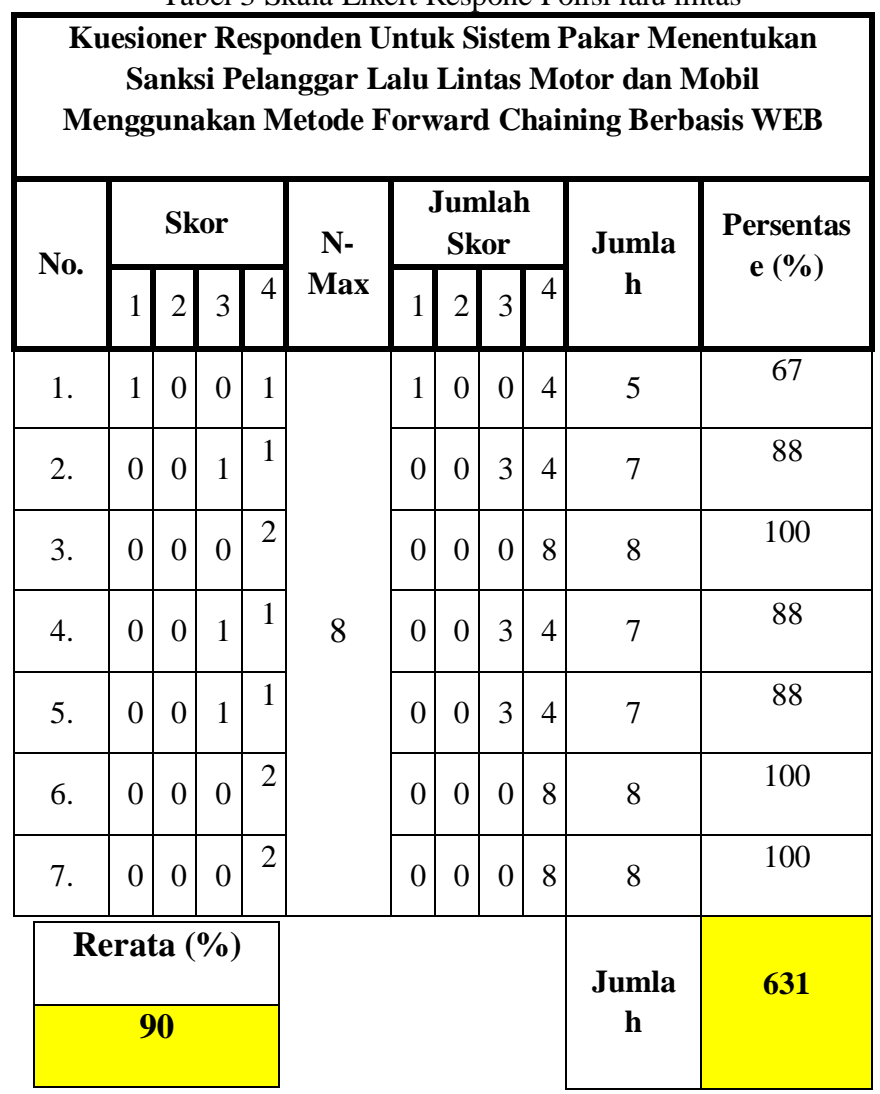

Tabel 4 Skala Likert Respone Staff Pidana Umum MA RI/Sarjana Hukum

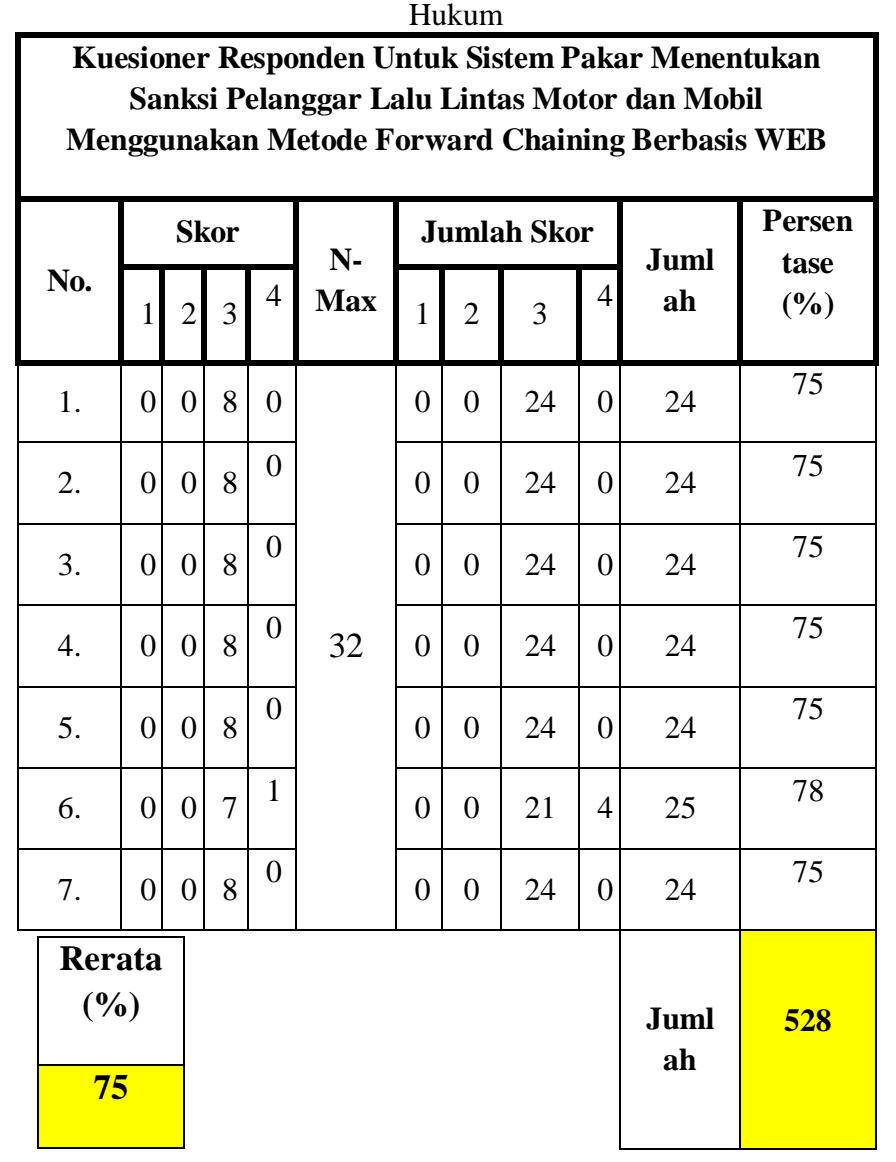

\section{Kesimpulan}

Metode penelitian yang digunakan dalam pengumpulan data kebutuhan sistem dengan menggunakan metode wawancara, hasil dari wawancara menghasilkan data yang dibutuhkan untuk merancang sistem pakar lalu lintas ini.

Dengan memberi beberapa contoh kasus pada sistem dalam menggunakan dua penelusuran yaitu secara tertulis dan sistematis menghasilkan kecocokan antara kedua penelusuran tersebut.

Dalam mengukur validitasi kebenaran hasil dari konsultasi pengguna ke sistem, peneliti sudah menyebarkan kuesioner skala likert ke pengendara, polisi, dan ke pakar hukum, dengan rerata keberhasilan 93\% untuk pengendara, 90\% untuk polisi, dan $75 \%$ untuk pakar hukum. Dengan acuan kategori peneliti bahwa hasil keseluruhan persentase sistem pakar ini $77 \%$ atau setuju. 


\section{Kepustakaan}

[1]

F. Yenila, Y. Wiyandra, "Expert System Pelanggaran Kendaraan Bermotor di Indonesia dengan Metode Forward Chaining". Jurnal Teknologi, Vol. 6, No. 2, hlm. 1-6. Desember 2016.

[2]

Khairah, "Jalan (LLAJ) dengan Menggunakan Metode Forward Chaining (Studi Kasus Pengadilan Negeri Tembilahan)". Jurnal SISTEMASI, Vol. 3, No. 1, hlm. 15-27. Januari 2014.

[3] A. Maulana, "Kompas.com," September 2018. [Online]. Available:

https://otomotif.kompas.com/read/2018/09/07/152521615/pe ngguna-jalan-harus-dipaksa-tertib-berlalu-lintas. [Diakses 07 September 2018].

G. M. R. Wahyuni dan Y. Yudihartanti, "Aplikasi Diagnosa Kerusakan Gitar Listrik Dengan Forward chaining Berbasis Android", JUTISI, vol. 5, no. 1, hlm. 933-942. April 2016.

[5] W. Verina, "Penerapan Metode Forward Chaining untuk Mendeteksi Penyakit THT", Jatisi, Vol. 1, No. 2, hlm. 123138. Maret 2015.
[6]

R. Afnur, T. Sriwahyuni, A. Hadi, "Rancangan Bangun Aplikasi Sistem Pakar untuk Diagnosis Kerusakan Sepeda Motor Matic Menggunakan Metode Forward chaining", Jurnal Voasional Teknik Elektronika \& Informatika, vol. 4, no. 2, Juli - Desember 2016. [Online]. Available: https://studylibid.com/doc/404271/sistem-diagnosis-

kerusakan-pada-alat-musik-gitar-elektrik.

[7] Deefa (2012), "Expert System For Car Troubleshooting", International Journal For Research In Science \& Advanced Technologies, Issue-I, Volume-I, 046-049

[8] Andi, (2003), Pengembangan Sistem Pakar Menggunakan Visual Basic. Yogyakarta : Andi

[9] Akhmad, dkk, (2010), Pengembangan Sistem Pakar Untuk Mendiagnosis Kerusakan Diesel : ISSN 2087-2607

[10] Kusrini, (2006), Sistem Pakar Teori dan Aplikasi. Yogyakarta : Andi Offset

[11] Sutojo,T, dkk, (2010), Kecerdasan Buatan. Yogyakarta : Andi Offset 